\title{
RESTORATIVE JUSTICE APPROACH IN THE SETTLEMENT OF CHILDREN'S CASES IN INDONESIA
}

\author{
Trinita Yulinda Sirait, Irma Cahyaningtyas \\ Faculty of Law, Diponegoro University \\ Jl. Imam Bardjo, S.H. No.1-3, Kampus Pleburan, Semarang, Central Java, Indonesia \\ E-mail: trinita_yulinda@yahoo.co.id
}

\begin{abstract}
Restorative justice is a way to resolve criminal cases involving the community, victims, and perpetrators of crime to achieve justice for all parties so that it is expected to create the same conditions as before the crime and prevent further crime. However, implementation is often overlooked in children who commit crimes. The research method used in this study is the normative legal research method with the legislation approach and conceptual approach. This research shows the case of children before the law $(A B H)$ brought in the judicial process must always prioritize the principle of the best interests of children, and the process of punishment is a last resort. Cases can be resolved through informal mechanisms based on standard guidelines. This form of informal handling can be done by diversion through a mediation process facilitated by law enforcement at every level to achieve restorative justice through diversion. Thus, the core of restorative justice is healing, moral learning, community participation and attention, dialogue, forgiveness, responsibility and making changes, all of which are guidelines for the recovery process in the perspective of restorative justice.
\end{abstract}

\section{Keywords: Restorative Justice; Children; Indonesia}

\section{A. INTRODUCTION}

Children as one of the human resources and the next generation of the nation should receive special attention, both from parents, the community and the government. ${ }^{1}$ This aims in the context of fostering children to realize strong and quality human resources. ${ }^{2}$ Also, the interests of children must be used as a basis for guidance by those responsible for the education and guidance of the child concerned, and of course the main holder of these responsibilities, namely parents. ${ }^{3}$ Today, in Indonesia the development and advancement of technology indirectly also triggers the development and diversity of criminal behavior in society. Crime behavior can occur to anyone not only adults but also often happens to children. This is because children are raised in an atmosphere of conflict, tend to experience mental anxiety that can encourage children to do negative actions, which are categorized as

1 Randy Pradityo. "Restorative Justice dalam Sistem Peradilan Pidana Anak." Jurnal Hukum dan Peradilan, 5(3), 2016, 319-330, p. 320

${ }^{2}$ Hari Sutra Disemadi. “Adultery Child Status In Islamic Law And In The Civil Code.” Legal Standing: Jurnal Ilmu Hukum, 3(2), 2019, 20-31, p. 21

${ }^{3}$ Nur Hidayati. "Perlindungan Anak terhadap Kejahatan Kekerasan Seksual (Pedofilia)." Ragam Jurnal Pengembangan Humaniora, 14(1), 2014, 68-73, p. 69 
delinquents. The mischief that is caused, could even lead to actions against the law. For that we need legal protection for children in Indonesia. ${ }^{4}$

Protection of children in our constitution is stated very firmly that the state guarantees children's rights to survival, growth and development and to guarantee protection from violence and discrimination. ${ }^{5}$ The legal protection of children is an obligation for all of us to remember children as the next generation of the nation who have a strategic role in realizing the ideals of the nation, therefore children must get development and protection so that they can grow and develop properly. ${ }^{6}$ Children are a group that is vulnerable to a crime either as a victim, witness, or as a perpetrator of a crime. ${ }^{7}$ In the provision of Article 1 number 2 of Law Number 35 of 2014 concerning amendments to Law Number 23 of 2002 concerning Child Protection, it is determined that child protection is all activities to guarantee and protect children and their rights so that they can live, grow, develop, and participate, optimally in accordance with human dignity and dignity, and receive protection from violence and discrimination.

Children as criminals are called delinquent children or in criminal law are referred to as juvenile delinquency. ${ }^{8}$ Romli Atmasasmita argues that juvenile delinquency is any act or behavior of a child under the age of 18 years and has not married which is a violation of the norms of applicable law and can endanger the personal development of the child. ${ }^{9}$

Facing and overcoming these various problems, it is necessary to consider the position of the child with all the characteristics and characteristics that are typical as perpetrators of a crime. ${ }^{10}$ Not seeing whether the act is based on thoughts, feelings and desires but must also see various things that can affect children to commit criminal acts. Therefore, the role of parents and the surrounding community is required. In dealing with children as perpetrators of crime, law enforcement officials must always pay attention to the condition of children that are different from adults. The nature of the child as a person who is still unstable, the future of the child as an asset of the nation, and the position of the child in a society that still needs protection can be used as a basis for finding alternative solutions how to prevent children from a formal criminal justice system, placing children in prison, and stigmatization against the position of the child as a convict. ${ }^{11}$

\footnotetext{
${ }^{4}$ Dheny Wahyudi. "Perlindungan Terhadap Anak yang Berhadapan dengan Hukum Melalui Pendekatan Restorative Justice.” Jurnal Ilmu Hukum Jambi, 6(1), 2015, 143-163, p. 144

${ }^{5}$ Dheny Wahyudi. Ibid., p. 146

${ }^{6}$ Randy Pradityo. Op.Cit., p. 321

${ }^{7}$ Sontan Merauke Sinaga, \& Elvi Zahara Lubis. "Perlindungan Hukum terhadap Anak Yang Melakukan Kejahatan dalam Persidangan Anak.” Jurnal Mercatoria, 3(1),2010,52-57, p. 53

${ }^{8}$ Ratri Novita Erdianti \& Sholahuddin Al-Fatih, Fostering as an Alternative Sanctin for Juveniles in The Perspective of Child Protection in Indonesia, Journal of Indonesian Legal Studies, Vol. 3 No. (1), 2019.

${ }^{9}$ Dheny Wahyudi. Op.Cit., p. 147

${ }^{10}$ Randy Pradityo. Op.Cit., p. 322

${ }^{11}$ Yutirsa Yunus. “Analisis Konsep Restorative Justice Melalui Sistem Diversi Dalam Sistem Peradilan Pidana Anak Di Indonesia.” Jurnal Rechts Vinding: Media Pembinaan Hukum Nasional, 2(2), 2013, 231-245, p. 240
} 
Protection of children dealing with the law in the criminal justice process so far has often been positioned as an object and tends to harm the child. ${ }^{12}$ In the case of children sometimes children as perpetrators, victims and witnesses in an action for that need serious handling and must be done by officials who understand the child's problems. ${ }^{13}$ In Law Number 11 Year 2012 concerning the Juvenile Criminal System. Protection of children in conflict with the law is progressing in the process of settling children's cases not only through the judicial process but can also be completed outside the judicial process through diversion with a restorative justice approach. ${ }^{14}$

This means that not all problems of juvenile delinquents must be resolved through formal justice, and provide an alternative solution to the approach of justice in the best interests of the child and by considering justice for victims known as the restorative justice approach. ${ }^{15}$ Handling with this approach is also carried out on the grounds to provide an opportunity for lawbreakers to become good people again through non-formal channels by involving community resources, as well as trying to provide justice to the case of children who have already committed a crime to the law enforcement officers. The research method used in this paper is normative juridical research. The type of data used is secondary data. Secondary data in the form of data obtained from library studies in the form of legal materials such as legislation, books, journals materials using qualitative analysis.

\section{B. RESULTS AND DISCUSSION}

\section{The Basic Concept Of The Restorative Justice Approach}

In criminal law enforcement practices we often hear the term Restorative Justice, or Restoration Justice which in Indonesian translation is called the restoration of justice. ${ }^{16}$ Restorative Justice contains the meaning, namely: "a restoration of relations and redemption of wrongdoing by the perpetrators of a crime (his family) against victims of the crime (his family) (peace efforts) outside the court of law with the intent and purpose that legal issues arising from the occurrence of acts the crime can be resolved properly with the achievement of agreements and agreements between the parties". 17

Restorative Justice in principle is a philosophy (basic guideline) in the peace process outside the judiciary by means of mediation or deliberation in achieving a justice expected by the parties involved in the criminal law, namely the perpetrators of criminal acts (their

${ }^{12}$ Randy Pradityo. Op.Cit., p. 324

${ }^{13}$ Dheny Wahyudi. Op.Cit., p. 149

14 Septa Candra. "Restorative Justice: Suatu Tinjauan Terhadap Pembaharuan Hukum Pidana Di Indonesia. Jurnal Rechts Vinding: Media Pembinaan Hukum Nasional, 2(2), 2013, 263-277, p. 267

${ }^{15}$ Dheny Wahyudi. Op.Cit., p. 151

${ }^{16}$ Allison Morris. "Critiquing the critics: A brief response to critics of restorative justice." British Journal of Criminology, 42(3),2002, 596-615, p. 598

${ }^{17}$ Allison Ann Payne, \& Kelly Welch. "Restorative justice in schools: The influence of race on restorative discipline." Youth \& Society, 47(4), 2015, 539-564, p. 551 
families) and victims of criminal acts (family) to find the best solution agreed and agreed by the parties. Restorative justice is said to be a philosophy (basic guideline) in achieving justice carried out by parties outside the judiciary because it is the basis of the peace process of the perpetrators of criminal acts (their families) and victims (their families) due to the emergence of victims / losses from these criminal acts. ${ }^{18}$

Thus it can be said that Restorative Justice contains basic principles including: 1). Strive for peace outside the court by the perpetrators of criminal acts (their families) against victims of criminal acts (their families); 2). Allowing the perpetrators of a criminal offense (his family) to be responsible for making amends by compensating for the damages resulting from the crime he committed; and 3). Resolving criminal law problems that occur between the perpetrators of the crime and the victims of the crime if an agreement and agreement between the parties is reached.

Efforts to resolve problems outside the court carried out by the perpetrators of criminal acts (their families) and victims of criminal acts (their families) will later be expected to become the basis for consideration in the process of investigating criminal offenses in court in the imposition of criminal sanctions by judges / judges. So that it can be interpreted that Restorative Justice is a series of processes of solving criminal problems outside the court that aims to restore (restore) the relationship between the parties and the losses suffered by victims of crime and are expected to be used as a basis for consideration for criminal court judges in lightening sanctions criminal sentences against the perpetrators of these criminal acts.

Restorative.Justice in criminal law must aim to restore the situation as it was before the crime. When someone violates the law, the situation will change. So that is where the role of law is to protect the rights of every victim of crime. In the conventional criminal justice process there are known restitution or compensation to the victim, whereas restoration has a broader meaning. Restoration involves restoring the relationship between the victim and the perpetrator. The restoration of this relationship can be based on mutual agreement between the victim and the perpetrator. The victim can convey about the loss he suffered and the perpetrator was allowed to make it up, through compensation mechanisms, peace, social work, and other agreements. Why does this matter?. Because the conventional criminal process does not provide space for parties involved in violations of criminal law in this case the perpetrators of the crime and victims of the crime to actively participate in conducting mediation / deliberation in solving their problems outside the court. ${ }^{19}$

Every indication of a criminal act, without taking into account the escalation of his actions, will continue to be rolled into the realm of law enforcement which only becomes the jurisdiction of law enforcement. ${ }^{20}$ Active participation from the community seems to be no

\footnotetext{
${ }^{18}$ Sekhroni. "Criminal Liability dan Diversi Terhadap Tindak Pidana Anak dalam Sistem Peradilan Anak di Indonesia." UNIFIKASI: Jurnal Ilmu Hukum, 3(1), 2016, 36-64, p. 41

${ }^{19}$ Nancy Rodriguez. "Restorative justice at work: Examining the impact of restorative justice resolutions on juvenile recidivism." Crime \& Delinquency, 53(3), 2007, 355-379, p. 361

${ }^{20}$ Allison Morris., Op.Cit., p. 600
} 
longer important, all of which only lead to convictions or punishment (imposing criminal sanctions) without seeing the existence of restorative justice that has been done and agreed upon by the parties.

It is time for the philosophy of Restorative Justice to become a consideration in the criminal law implementation system and be included in the new Criminal Law Regulations $(K U H P)$, especially for criminal offenses complaints (Klacht delict) so that the deterrence is based on the conditions for the creation of justice and balance of legal treatment of perpetrators of acts criminal offenses and victims of criminal acts can be achieved well, without having to always use criminal sanctions (imprisonment) in the final settlement. Because the deterrent effect as the ultimate goal of punishment (imprisonment) the perpetrators of criminal acts are no longer reaching their targets as expected. There needs to be a breakthrough in the implementation of the criminal system in Indonesia, not only through imprisonment but also through the application of Restorative Justice. ${ }^{21}$

\section{Restorative Justice As Aim Of Diversion Implementation In Children Criminal Justice Systems}

The Indonesian Criminal Law System is entering a new phase in its development. One form of renewal in Indonesian Criminal Law is the regulation of criminal law in the perspective and achievement of justice for the improvement and restoration of circumstances after criminal justice events and processes known as restorative justice which is different from retributive justice (emphasizing justice in retaliation ) and restitutive justice (emphasizing fairness in compensation). When viewed from the development of criminal law and the nature of modern convictions, it has introduced and developed what is called the "Doer-Victims" Relationship approach. A new approach that has replaced the approach of deeds or actors or "daad-dader straftecht". ${ }^{22}$ Legal experts have introduced a formula of justice, especially in the enforcement of human rights (HAM), that there are 3 aspects of the approach to building a legal system in the context of modernization and legal reform, namely in terms of structure, substance, and legal culture all of which are feasible to run integrally, simultaneously and parallel. $^{23}$

Children are part of citizens who must be protected because they are the nation's generation in the future who will continue the leadership of the Indonesian people. Every child besides being obliged to get formal education such as a school is also obliged to get moral education so that they can grow into a useful figure for the nation and state. In accordance with the provisions of the Convention on the Rights of the Child which was ratified by the Indonesian government through Presidential Decree Number 36 of 1990, then

${ }^{21}$ Nancy Rodriguez. Op.Cit., p. 372

${ }^{22}$ Febrina Annisa. "Penegakkan Hukum Terhadap Anak Yang Melakukan Tindak Pidana Pencabulan Dalam Konsep Restorative Justice.” ADIL: Jurnal Hukum, 7(2), 2016, 202-211, p. 209

${ }^{23}$ Selamet Riadi. "Peran Penyidik Polri Dalam Penerapan Diversi Terhadap Anak Yang Berkonflik Dengan Hukum (Studi Di Ppa Polres Lobar).” Jurnal IUS Kajian Hukum dan Keadilan, 4(2), 2016, 124-136, p. 129 
also set forth in Law Number 4 of 1979 concerning Child Welfare and Law Number 23 of 2002 concerning Child Protection and Law Number 11 of 2012 concerning the Criminal Justice System for Children (SPPA Law) all of which state the general principles of child protection, namely non-discrimination, the best interests of children, survival and development and respect for children's participation.

Legal protection for children can be done as an effort to protect the law against various freedoms and children's rights. The protection of children also includes interests related to child welfare. Protection of children dealing with the law $(\mathrm{ABH})$, is a shared responsibility of law enforcement officials. Not only children as perpetrators but also includes children who are victims and witnesses. Law enforcement officials involved in handling ABH should not only refer to Law Number 11 of 2012 concerning the Child Criminal Justice System (SSPPA Law) or other legislation relating to the handling of $\mathrm{ABH}$, but prioritizes peace over the formal legal process which came into force 2 years after the SPPA Act was enacted or 1 August 2014 (Article 108 of the SSPPA Law).

The Supreme Court responded to the Child Criminal Justice System Act very progressively. Indonesian Supreme Court Chief Justice Muhammad Hatta Ali signed Supreme Court Regulation (PERMA) Number 4 of 2014 concerning Guidelines for the Implementation of Diversity in the Juvenile Justice System even before Government Regulations which are derived from the SPPA Law were issued. The important point of the PERMA is that the Judges are required to resolve the $\mathrm{ABH}$ problem with the Diversi program which is a legal procedure that is still very new in the system and renewal of criminal law in Indonesia. ${ }^{24}$ Besides that, this PERMA contains procedures for implementing diversion that is the guide of Judges in the settlement of juvenile crimes, bearing in mind that there is no regulation that contains specific procedural law for the diversion of the juvenile justice system. ${ }^{25}$

The juvenile justice system is all elements of the criminal justice system that are involved in handling ABH cases. Police, Attorney and Court and Community Guidance or Correctional Institution, Advocates or assistance providers, Special Child Development Institution (LPKA), Temporary Child Placement Institution (LPAS) and Social Welfare Organization (LPKS) as institutions or institutions that treat $\mathrm{ABH}$ starting from children in contact with the justice system, determine whether the child will be released or processed in juvenile court to the stage when the child will be placed in choices, ranging from being released to being included in a punitive institution in the corridor of restorative justice. This is consistent with: 1). United Nations Declaration of 2000 concerning Principal Principles on the Use of Restorative Justice Programs in Criminal Matters (United Nations Declaration on The Basic Principles on the Use of Restorative Justice Programs in Criminal Matters); 2). Vienna Declaration on Crime and Justice (Vienna Declaration on Crime and Justice: "Meeting the

${ }^{24}$ Eva Sitindaon, Abul Khair, \& Marlina Marlina. "Sistem Pemidanaan terhadap Anak sebagai Pelaku Tindak Pidana Sebelum dan Sesudah Pengaturan Restoratif Justice di Indonesia.” Jurnal Mahupiki, 1(1), 2012, $1-25$, p. 12

${ }^{25}$ Nancy Rodriguez., Op.Cit., p. 360 
Challenges of the Twenty-First Century") items 27-28 concerning Restorative Justice; and 3). XI United Nations Congress in Bangkok in 2005 on the Prevention of Crime and Criminal Justice (Eleventh United Nations Congress on Crime Prevention and Criminal Justice) in item 32: "Strategic alliance in the prevention of criminal acts and criminal justice (Synergies and Responses: Strategic Alliances) in Crime Prevention and Criminal Justice" ${ }^{26}$

According to the SPPA Diversi Law is the transfer of the settlement of cases of Children from criminal justice processes to processes outside of criminal justice, which aim to: 1). Achieve peace between victims and children; 2). Resolving cases of Children outside the judicial process; 3). Preventing Children from deprivation of independence; 4). Encouraging the community to participate; and 5). Instilling a sense of responsibility to the child.

According to PERMA 42014 Diversity Conference is a discussion between parties involving children and parents/guardians, victims and/or parents/guardians, Community Guidance, Professional Social Workers, representation and other parties involved to reach agreement on a diversion through an approach restorative justice. Whereas the Facilitator is a judge appointed by the Chief of the Court to handle the case of the child concerned. Diversion is the transfer of processes in a long and very rigid child case resolution system. Mediation or dialogue or deliberation as an inseparable part of diversion to achieve restorative justice.

Punishment for child offenders does not then achieve justice for the victim, bearing in mind that from the other side it still leaves its unresolved problems even though the perpetrators have been sentenced. Seeing the principles of child protection, especially the principle of prioritizing the best interests of children, it is necessary to process the settlement of cases of children outside the criminal mechanism or commonly called diversion. Punishment institutions are not a way to solve children's problems because they are prone to violations of children's rights. ${ }^{27}$

Therefore we need an event and procedure in the system that can accommodate settlement of cases, one of which is to use a restorative justice approach, through a legal reform that does not merely change the law but also modifies the existing criminal justice system, so that all objectives what is needed by the law is achieved. One form of the restorative justice mechanism is a dialogue among Indonesian people better known as "deliberation to reach consensus". ${ }^{28}$ So that diversion, especially through the concept of restorative justice, becomes a very important consideration in resolving criminal cases conducted by children. ${ }^{29}$ If the agreement of diversion is not carried out entirely by the parties based on the report from the Community Guidance Correctional Institution, the Judge shall

${ }^{26}$ Hasibuan, Lidya Rahmadani, et al. "Restorative Justice Sebagai Pembaharuan Sistem Peradilan Pidana Berdasarkan UU No. 11 Tahun 2012 Tentang Sistem Peradilan Pidana Anak.” USU Law Journal, 3(3), 2015, 64-71, p. 67-68

${ }^{27}$ Beniharmoni Harefa. "Diversi Sebagai Perlindungan Hukum Terhadap Hak Asasi Anak Dalam Sistem Peradilan Pidana Anak Di Indonesia." Jurnal Komunikasi Hukum (JKH), 1(1), 2015, 1-13, p. 9

${ }^{28}$ Sontan Merauke Sinaga, \& Elvi Zahara Lubis., Op.Cit., p. 54

${ }^{29}$ Irma Cahyaningtyas. "Pembinaan Anak Pidana Di Lembaga Pembinaan Khusus Anak Dalam Perspektif Restorative Justice." NOTARIUS, 8(2), 2015, 342-353, p. 345 
continue the examination of the case by the Criminal Procedure Law for the Children, and the Judge in dropping his decision must consider the implementation of some diversion agreements. $^{30}$

In PERMA 4 of 2014 it is explained that Diversion is applied to children who are 12 (twelve) years old but not yet 18 (eighteen) years old or have 12 (twelve) years old even though they have never married but are not yet 18 (eighteen) years old, who is suspected of a criminal offense (article 2). This PERMA also regulates the stages of deliberation, where facilitators appointed by the Chairperson of the Court must provide opportunities to: 1). Child to be heard information about the indictment; 2). Parents/Guardians to convey matters relating to the child's actions and the expected form of settlement; and 3). Victim/Child Victim/Parent/Guardian to provide the expected response and form of settlement.

If deemed necessary, the diversion facilitator can call on community representatives or other parties to provide information to support the settlement and/or can hold a separate meeting (Caucus). ${ }^{31}$ Caucus is a separate meeting between the Diversity Facilitator and one party that is known by the other party.

\section{CONCLUSION}

Children are a mandate from God Almighty who inheres dignity and dignity as whole human beings. The rights of every child must be upheld without the child asking. Children cases before the law $(\mathrm{ABH})$ brought in the judicial process are serious cases, they also must always prioritize the principle of the best interests of children, and the punishment process is the last resort (Ultimum Remedium) while still not ignoring the rights of the rights child. Beyond that child, cases can be resolved through non-formal mechanisms based on standardized guidelines. Forms of non-formal handling can be done with diversion as a mediation process facilitated by law enforcement at every level to achieve restorative justice that can be resolved by requiring children who are in conflict with the law to attend education or training at certain institutions such as other actions carried out with remedies for children and victims, or if forced to do punishments of children's rights should not be ignored. So that in the end non-formal handling can be carried out well if it is balanced with efforts to create a conducive justice system.

Diversion can also be described as a system where the facilitator manages the process of resolving parties to reach a satisfactory resolution as restorative justice. The tradition and mechanism of deliberation to reach consensus is a concrete manifestation in strengthening the law that has lived in society for a long time. Thus, the core of restorative justice is healing, moral learning, community participation and attention, dialogue, forgiveness, responsibility

\footnotetext{
${ }^{30}$ Septa Candra., Op.Cit., p. 270

${ }^{31}$ Sri Rahayu. "Diversi Sebagai Alternatif Penyelesaian Perkara Tindak Pidana Yang Dilakukan Anak Dalam Perspektif Sistem Peradilan Pidana Anak.” Jurnal Ilmu Hukum Jambi, 6(1), 2015, 127-142, p. 137
} 
and making changes, all of which are guidelines for the process of restoration in the perspective of restorative justice.

\section{REFERENCES}

Allison Ann Payne \& Kelly Welch. Restorative Justice in Schools: The Influence of Race on Restorative Discipline. Youth \& Society, Vol. 47 No. (4), 2015.

Allison Morris. Critiquing The Critics: A Brief Response to Critics of Restorative Justice. British Journal of Criminology, Vol. 42 No. (3), 2002.

Beniharmoni Harefa. Diversi Sebagai Perlindungan Hukum Terhadap Hak Asasi Anak Dalam Sistem Peradilan Pidana Anak Di Indonesia. Jurnal Komunikasi Hukum (JKH), Vol. 1 No. (1), 2015.

Dheny Wahyudi. Perlindungan Terhadap Anak yang Berhadapan dengan Hukum Melalui Pendekatan Restorative Justice. Jurnal Ilmu Hukum Jambi, Vol. 6 No. (1), 2015.

Eva Sitindaon, Abul Khair \& Marlina Marlina. Sistem Pemidanaan terhadap Anak sebagai Pelaku Tindak Pidana Sebelum dan Sesudah Pengaturan Restoratif Justice di Indonesia. Jurnal Mahupiki, Vol. 1 No. (1), 2012.

Febrina Annisa. Penegakkan Hukum Terhadap Anak Yang Melakukan Tindak Pidana Pencabulan Dalam Konsep Restorative Justice. ADIL: Jurnal Hukum, Vol. 7 No. (2), 2016..

Hari Sutra Disemadi. Adultery Child Status In Islamic Law And In The Civil Code. Legal Standing: Jurnal Ilmu Hukum, Vol. 3 No. (2), 2019.

Hasibuan, Lidya Rahmadani, et al. Restorative Justice Sebagai Pembaharuan Sistem Peradilan Pidana Berdasarkan UU No. 11 Tahun 2012 Tentang Sistem Peradilan Pidana Anak. USU Law Journal, Vol. 3 No. (3), 2015.

Irma Cahyaningtyas. Pembinaan Anak Pidana Di Lembaga Pembinaan Khusus Anak Dalam Perspektif Restorative Justice. NOTARIUS, Vol. 8 No. (2), $2015 .$.

Nancy Rodriguez. Restorative Justice At Work: Examining The Impact Of Restorative Justice Resolutions On Juvenile Recidivism. Crime \& Delinquency, Vol. 53 No. (3), 2007.

Nur Hidayati. Perlindungan Anak terhadap Kejahatan Kekerasan Seksual (Pedofilia). Ragam Jurnal Pengembangan Humaniora, Vol. 14 No. (1), 2014.

Randy Pradityo. Restorative Justice dalam Sistem Peradilan Pidana Anak. Jurnal Hukum dan Peradilan, Vol. 5 No. (3), 2016.

Ratri Novita Erdianti \& Sholahuddin Al-Fatih, Fostering as an Alternative Sanctin for Juveniles in The Perspective of Child Protection in Indonesia, Journal of Indonesian Legal Studies, Vol. 3 No. (1), 2019. 
Sekhroni. Criminal Liability dan Diversi Terhadap Tindak Pidana Anak dalam Sistem Peradilan Anak di Indonesia. UNIFIKASI: Jurnal Ilmu Hukum, Vol. 3 No. (1), 2016.

Selamet Riadi. Peran Penyidik Polri Dalam Penerapan Diversi Terhadap Anak Yang Berkonflik Dengan Hukum (Studi di PPA Polres Lobar). Jurnal IUS Kajian Hukum dan Keadilan, Vol. 4 No. (2), 2016.

Septa Candra. Restorative Justice: Suatu Tinjauan Terhadap Pembaharuan Hukum Pidana Di Indonesia. Jurnal Rechts Vinding: Media Pembinaan Hukum Nasional, Vol. 2 No. (2), 2013.

Sontan Merauke Sinaga, \& Elvi Zahara Lubis. Perlindungan Hukum terhadap Anak Yang Melakukan Kejahatan dalam Persidangan Anak. Jurnal Mercatoria, Vol. 3 No. (1), 2010.

Sri Rahayu. Diversi Sebagai Alternatif Penyelesaian Perkara Tindak Pidana Yang Dilakukan Anak Dalam Perspektif Sistem Peradilan Pidana Anak. Jurnal Ilmu Hukum Jambi, Vol. 6 No. (1), 2015.

Yutirsa Yunus. Analisis Konsep Restorative Justice Melalui Sistem Diversi Dalam Sistem Peradilan Pidana Anak di Indonesia. Jurnal Rechts Vinding: Media Pembinaan Hukum Nasional, Vol. 2 No. (2), 2013. 